\title{
Study on the Ability Improvement of Diplomatic Etiquette of Naval College Cadets
}

\author{
Rui Guo ${ }^{1, *}$ and Jiajia Han ${ }^{1}$ \\ ${ }^{1}$ Department of Warships Command, Dalian Naval Academy, Dalian, China \\ *Corresponding author's e-mail: msegr@163.com
}

\begin{abstract}
To improve the diplomatic etiquette ability of naval college cadets, this article develops study on several forms to improve methods of naval diplomatic etiquette. Firstly, this article introduces the basic meaning of naval diplomatic etiquette. Afterward, it analyzes eight aspects of diplomatic etiquette ability of naval college cadets, including promoting the Chinese culture, improving the understanding of communication, reforming the existing international naval diplomatic etiquette, and so on. Finally, this article discusses the ways to improve the diplomatic etiquette ability of the cadets, including how to strengthen the theoretical foundation of naval diplomacy etiquette, learn the foreign languages, equipment and customs in advance, and reinforce the practical exercise. The conclusion herein can be used as a reference for improving diplomatic etiquette training for naval colleges.
\end{abstract}

Keywords: Navy; College; Cadet; Diplomatic Etiquette; Ability

\section{INTRODUCTION}

Over the past few years, the naval diplomatic activities have developed a lot in China. From December 2008 to June 2021, 38 convoys were deployed to the Gulf of Aden for escort, and they visited many countries throughout the journey [1]. Meanwhile, some naval colleges organized cadets to exchange views with abroad. For example, the Dalian Naval Academy paid a friendly visit to Brunei, New Zealand and other five Asia-Pacific countries between September and November 2019 [2].

With the increase of diplomatic activities with foreign countries, naval college cadets have more opportunities to communicate with foreigners, including receiving visits and paying visit to other countries. Therefore, the higher requirements have been raised for the training of diplomatic abilities. Hereon, the answer to the following two questions is required. Firstly, what do the naval diplomatic etiquette abilities of new era include? Secondly, how to improve the diplomatic etiquette abilities of naval college cadets? With regards to the aforesaid two questions, this article develops study on some capabilities of diplomatic etiquette for naval college cadets and explores some ways for naval cadets to enhance diplomatic etiquette on the basis of introducing naval diplomatic etiquette.

\section{INTRODUCTION ON THE NAVAL DIPLOMACY ETIQUETTE}

Etiquette usually refers to the people's specific behaviours, which are conducted in the interpersonal communication with the certain, conventional procedures or ways to show self-discipline, respect to other people [3]. Any etiquette behaviour is composed of 7 elements [4], such as subject, object, medium, content, time, venue, effect and etc. According to the aforesaid elements, etiquette can be divided into government etiquette, business etiquette, foreign-related etiquette, and other types. Naval diplomatic etiquette belongs to the foreign-related etiquette.

Naval diplomatic etiquette refers to the customary practice in foreign exchanges, which is used to maintain its image and to show respect and friendship to foreigners. And it is the norms that naval officers and soldiers must follow in friendly exchanges with foreign countries. The etiquette mainly consists of [5]: full dress, full lights, raising the national flag, setting a guard of honour and military band, lining up on the deck, whistle, playing the national anthem or welcome song, firing salutes, meeting the local officials, holding the deck reception and so on.

Naval has the most etiquette in all military services. This is related to its long-time sea mission and frequent communication with other countries. The U.S. military believes that the value of naval diplomacy is "to create an atmosphere of mutual respect, humility, and courtesy in social relationships." [6] So warships visiting abroad act as "friendship messengers" and there is no longer a more appropriate "friendship messenger" than the warships visiting abroad. The famous George W. Bush Admiral S. Barton said [7]: "Diplomatic etiquette is beneficial not only for the senior officers, but also for all officers and soldiers. The national pride and the tradition of special attention to diplomatic etiquette must be passed on with an aim to make our country and tradition to last forever. 


\section{ANALYSIS ON THE ABILITY OF NAVAL DIPLOMATIC ETIQUETTE}

The diplomatic etiquette ability of naval college cadets mainly includes the following: the ability to safeguard national interests and national image, the ability to demonstrate the good manners of the People's Liberation Army of China (PLA), the ability to promote Chinese culture, the ability to learn from the others' advantages, the ability to improve understanding of communication, the ability to reform the current international naval diplomatic etiquette, the ability to enhance the sense of collective responsibility and honour, and the ability to expand personal vision and mind.

\subsection{The ability to safeguard national interests and the country's image}

Diplomacy represents the international exchange of state interests. It is an indispensable and important part of the activities of safeguarding national interests. It can be said that safeguarding the national interests is the first principle of diplomatic etiquette. In diplomatic occasions, for example, there may be statements by those with ulterior motives or by those unware of the truth which damage the image of China. These must be firmly refuted and must not be ignored. Meanwhile, the symbols representing the state image and the armed forces must be respected and preserved. For example, some celebrations will use the national flag or military flag. After the event, they might be scattered on the ground and trampled, we should carefully pick them up and fold in a good way.

\subsection{The ability to demonstrate the good manners of the PLA}

Firstly, we should show Chinese good manners in a proper way. The basic meaning is as said by the People's Daily editorial [8]: "Chinese diplomacy must adhere to traditional values. In foreign exchanges, we should better reflect the excellent cultural values of Chinese traditions, such as equal treatment, harmony in diversity, honesty and justice, to achieve success and to let others succeed as well. With these efforts, we let the world feel the mind and spirit of Chinese diplomacy, and bring new style and positive energy to international relations." In addition, it is necessary to show the good style of the PLA, i.e., to show the PLA's as a glorious image of mighty division, civilized division, ever-winning division.

\subsection{The ability to promote Chinese culture}

Chinese culture has a glorious history with thousands of years. Not only it has a broad and profound traditional culture, but also it is leading the trend of modern culture. Chinese government leaders have repeatedly stressed that we should adhere to the "four self-confidences", out of which the "cultural self-confidence" is to firmly believe that the socialist culture with Chinese characteristics, It aims to face modernization, to face the world, to face the future, national, scientific, and popular advanced culture. In terms of naval diplomatic etiquette, it displays not only the characteristics of the navy culture[9], but also displays calligraphy, martial arts, national musical instruments, tea art, handcrafted paper-cut and other national accomplishments, and displays Chinese cultural stories, heroes through the propaganda columns, postcards and so on.

\subsection{The ability to learn the advantages of others}

In the course of foreign contacts, the cadets will come into contact with other's military personnel and weapons. It's important to have a sense of careful observation of each other, as well as the sharpness and insight to find each other's advanced and backward points. With the development of economy and the improvement of national strength, Chinese navy has developed rapidly in recent years. Great progress has been made in personnel quality and weapon quality. Apart from the United States, Russia and other established naval powers, the majority of the world's naval power lags behind China. At this time the cadets should avoid blind arrogance, maintain modesty and prudence so as to complement each other in foreign exchanges.

\subsection{The ability to improve understanding of communication}

It is undeniable that there are many countries with a lot of prejudices and misunderstandings about China, which can lead to embarrassment and unhappiness in foreign exchanges. For example, they may compare the merits of China's Socialist with that of foreign Capitalism. They may ask what are the beliefs of naval academy cadets; whether China will follow the path of "a strong nation is bound to seek hegemony"; and so on. In this regard, the cadets should master a high level of communication skills so as to eliminate misunderstandings and enhance understanding. This requires cadets to strengthen learning and thinking at school, to cultivate the habit of reasoning, to behave neither humble nor pushy in foreign exchanges with an aim to seek common ground while reserving differences.

\subsection{The ability to reform the current international naval diplomatic etiquette}

Naval diplomatic etiquette not only represents the personal connotation cultivation and cultural level of naval officers and soldiers, but also demonstrates the country's international image and international status. The cadets 
still have a lot of work to do in exporting culture and values, and they have responsibilities and missions to bring more new styles and new energy to international naval diplomacy. In the course of learning diplomatic etiquette, the cadets should always have innovative ability, cultivate the initiative consciousness of reforming international naval diplomacy etiquette, and adhere to the strong spirit of "we should be the reformers of new era". In this way, we will lay a solid foundation for the future international naval diplomacy to infuse more and more Chinese elements.

\subsection{The ability to enhance the sense of collective responsibility and honour}

For naval cadets, the cultivation of diplomatic etiquette must not be regarded just as a personal matter. The naval cadets can master the knowledge and ability of diplomatic etiquette as quickly as possible through collective study and practice. From the other side, each cadet should develop a sense of collective responsibility and honour, and have the ability to enhance the sense of collective responsibility and honour. In the diplomatic etiquette occasion, one failure leads to another, so does success. For example, when a foreign navy holds a flag-raising or flag-lowering ceremony, even a cadet's recklessness will inevitably affect the overall image and honour of the whole army.

\subsection{The ability to expand personal vision and mind}

Naval cadets should cherish every opportunity to communicate with foreign countries. The navy belongs to the international military. Chinese navy will certainly go to the wider ocean in the future and will certainly deal with more and more countries and regions. It is important for every officer and soldier to have a wide horizon and mind. Therefore, college cadets must pay attention to expand their personal vision and mind and to observe the small world around from the large pattern in the process of diplomatic etiquette ability training. Firstly, they should learn to compare the Chinese and foreign navies in all directions, then to think about the future development of the navy, and finally implement how to fulfill the diplomatic etiquette.

\section{THE METHOD TO IMPROVE THE ABILITIES OF NAVAL DIPLOMATIC ETIQUETTE}

The main method to improve the diplomatic etiquette ability of naval cadets is "genuine knowledge comes from practice". On the basis of studying the theory of naval diplomatic etiquette, the cadets of naval colleges should know about foreign knowledge in advance and actively participate in various practices so as to improve their diplomatic etiquette ability quickly.

\subsection{To strengthen the foundation of the theoretical basis of naval diplomacy etiquette}

The main forms of naval diplomatic etiquette include: greeting and farewell, meeting, talking, banquets, signing ceremonies, recreational activities, tours, opening ceremonies, awarding medal, laying a wreath, celebrations, condolences, full dress, full lights, raising the national flag, setting up honour guard and military band, lining up on the deck, whistle, playing the national anthem or welcome song, firing salutes, meeting local officials, holding deck reception and so on. They can quickly enter the role in the post and do a good job in diplomatic etiquette only by mastering the aforesaid theoretical basis of the above-mentioned naval diplomatic etiquette.

\subsection{To learn foreign languages, equipment and customs in advance.}

The first step is to learn the naval professional foreign language. For example, for the same rank, the English description for the navy rank is very different from the ground force. If an American admiral is address as "general", he will certainly be unhappy because "general" is the ground force's rank. The second step is to understand the performance of foreign weapons and equipment so as to confirm with what is actually seen in the process of communication. Final step is to understand the relevant foreign cultural customs, master its pride and taboos, which helps to create a harmonious and pleasant communication environment.

\subsection{To strengthen the practice and exercise}

Before the cadets go to work, they should actively participate in the class scenario simulation, and simulate the diplomatic etiquette activities, such as welcome, meeting and talks. For example, participants are divided into many groups with about 10 members. After selecting the specific etiquette topics, they design their own etiquette order, flag hanging, activity rundown, scene and dialogues and other content. In addition, if there is an opportunity to receive foreign visits or visit foreign countries, it is important for participants to seize the opportunity to practise well. If there is no such occasion, they should participate in or organize the school's collective activities to compare with the theoretical knowledge learned.

\section{CONCLUSION}

With the rapid improvement of China's national strength, the great development of China's naval power has attracted 
the world's attention. With the increasing frequency of naval visits, naval college cadets have more and more opportunities to communicate with foreign countries, their diplomatic etiquette ability training is becoming more and more important. These abilities include (but are not limited to) the following eight articles described in the paper herein: the ability to safeguard national interests and national image, the ability to demonstrate the good manners of the PLA, the ability to promote Chinese culture, the ability to learn from the other's advantages, the ability to improve the understanding of communication, the ability to reform the current international naval diplomatic etiquette, the ability to enhance the sense of collective responsibility and honour, and the ability to expand personal vision and mind. During the stay in school, the cadets should strengthen the theoretical foundation of naval diplomatic etiquette, learn foreign languages, equipment and customs in advance, and strengthen practice and exercises. In this way, they can effectively improve the level of diplomatic etiquette, improve diplomatic quality, and then grow into excellent cadets who are good at disseminating Chinese culture, promoting friendship, and displaying the PLA's good image.

\section{REFERENCES}

[1] Website of GuangMing. The 38th Convoy of Our Navy Set Sail for the Gulf of Aden, 2021. DOI: https://m.gmw.cn/baijia/2021-05/16/1302297470.html.

[2] Website of Ministry of National Defense of the People's Republic of China. QiJiGuang Ship Set Sail to
Carry out the Long-distance Internship Mission and Visited Many Countries in the Asia-Pacific region, 2019. DOI:

http://www.mod.gov.cn/diplomacy/2019-09/21/content _4850844.htm.

[3] Jin Zhengkun. Foreign Etiquette Tutorials [M]. China Renmin University Press, Beijing. 2018:2.

[4] Zhou Jia Li. Foreign-related Etiquette [M]. China Machine Press, Beijing. 2017:5.

[5] Why Is There So Much Naval Etiquette [J]. Ship Materials and Markets, 2001, 1:50.

[6] Roy W. Cornell, William P. Mark. USA Navy Etiquette, Traditions and Habits [M]. Qiu Hao translate. Haichao Press, Beijing. 2009:5.

[7] Roy W. Cornell, William P. Mark. USA Navy Etiquette, Traditions and Habits [M]. Qiu Hao translate. Haichao Press, Beijing. 2009:115.

[8] China's Close Ties with the World Show the Broad Prospects of China's Diplomacy - the Third Editorial of Implementing the Spirit of the Central Conference on Foreign Affairs. 2014. People's daily, 2014-12-3(01).

[9] Su Yi. Pay Attention to the Role of the Dissemination of Navy Characteristics Culture [J]. Journal of Political Work, 2014, 10:62-63. 